\title{
HOW THE EPIDEMIOLOGY OF HODGKIN LYMPHOMA CHANGED IN DEBRECEN, HUNGARY
}

\author{
Authors, \\ László Pinczés, \\ Zsófia Miltényi, \\ Ádám Jóna, \\ Ferenc Magyari, \\ Kata Husi \\ and Árpád Illés \\ Authors Note \\ Department of Hematology, University of \\ Debrecen, Faculty of Medicine, Debrecen, \\ Hungary.
}

Introduction. Hodgkin lymphoma shows a well-known geographic pattern. Incidence also varies significantly by age, sex, ethnicity and socioeconomic status. These clinical pathological features of the disease are changing.

Patients and methods. 715 Hodgkin lymphoma patients' clinicopathological and treatment data were assessed in a maximum of ten-year periods. The patients were treated at the University of Debrecen, Department of Hematology from 1980 until the end of 2014.

Results. The first period (1980-89) contained 193, the second (1990-99) 199, the third (2000-09) 236 and the fourth (2010-14) 87 Hodgkin lymphoma patients. The mean age of the patients were $39,34.5,38$ and 36.8 years respectively. The male/female ratio was $1.29,1.23,1.03$ and 0.97 in order. A unimodal age group pattern can be seen in the first and second periods with an incidence peak between 20 and 29 years of age. Bimodal age group pattern was observed in the third and fourth periods with the first incidence peak between 20 and 29 years of age and the second between 50 and 59 years. The incidence of classical mixed cellularity (cMC) histological subtype is decreasing $(38 \%, 49 \%, 48 \%$ and $26 \%$; $\mathrm{p}<0.01)$ while classical nodular sclerosis (cNS) shows an increasing tendency $(21 \%, 28 \%, 30 \%$ and $50 \% ; \mathrm{p}<0.01)$. The first peak is predominantly caused by the cNS subtype in the third and fourth period, and the second peak caused by cMC subtype in the third and cNS in the fourth period. The number of advanced stage patients (59\%) is beyond the early stage patients (41\%) in the last observed period. The 5-year overall survival is increasing $(64.2 \%, 84.6 \%, 87 \%$ and $92 \%)$. Discussion. The changing patterns can be explained by the altered nature of the disease, changes in immunological features, environmental factors, socioeconomic status and development of diagnostic and therapy methods. 


\section{HOW THE EPIDEMIOLOGY OF HODGKIN LYMPHOMA \\ CHANGED IN DEBRECEN, HUNGARY}

\section{Introduction}

Hodgkin lymphoma (HL) is a lymphoid malignancy of B-cell origin characterized by the presence of malignant Hodgkin and ReedSternberg cells surrounded by an abundant reactive microenvironment. The disease can be divided into two groups by its pathogenesis and clinical features: the nodular lymphocyte predominant (NLP) and the classic subtypes (Swerdlow et al., 2016). The treatment of HL is one of the success stories of modern medicine. With modern

risk-adapted treatment regimens $80-90 \%$ of patients with HL can effectively be cured (Bonadonna et al., 2004; Engert et al., 2009). The etiology and risk factors for HL are not completely understood, however epidemiological studies pointed towards genetic, lifestyle- related and environmental background. The role of Ebstein-Barr virus (EBV) in the pathogenesis of HL is also supported by several sero-epidemiological findings, suggesting that EBV may be a transforming agent in HL and likely to be associated with mixed cellularity $\mathrm{HL}$ and younger patient population (Hjalgrim et al., 2007; Kaye, Izumi, \& Kieff, 1993; Weiss, Movahed, Warnke, \& Sklar, 2010).

Around 66000 new HL cases were diagnosed worldwide in $2012(0.5 \%$ of total cancer cases). HL is more frequent in developed countries, incidence rates are the highest in Northern America and the lowest in Eastern Asia. The incidence of HL shows differences worldwide, also mortality rates varying across the world (Ferlay et al., 2013).

Earlier epidemiological studies have revealed three patterns of the distribution in HL. Pattern 1, seen in developing countries and in patients of low socioeconomic status, shows an early childhood peak and a second peak around the age of fifty, with tumors predominantly of classical mixed cellularity (cMC) and classical lymphocyte depletion (cLD) subtypes with EBV positivity. Pattern 3 , seen in developed countries and in patients of high socioeconomic status, shows a bimodal age group pattern with a peak incidence among young adults with tumors mainly of classical nodular sclerosis (cNS) subtype with EBV negativity. Pattern 2, seen in countries with transitional economies, has an early childhood peak and a second (female) decade peak with equal frequencies of the $\mathrm{cMC}$ and $\mathrm{cNS}$ subtypes (Chang, Chen, Jones, \& Su, 2008; Landgren \& Caporaso, 2007).

Considering the changing patterns in the clinical pathological features in HL, the authors regarded worthwhile to investigate, whether the pathological or clinical nature of HL have changed in the past 5 years, since their previous report on this subject (Miltényi et al., 2011).

\section{Patients \& Methods}

The data of 715 HL patients, who were treated at the University of Debrecen, Hematology Department from 01/01/1980 until 31/12/2014 have been analyzed. Patient data was investigated in a maximum of ten year periods (first period: 1980-1989, second period: $1990-1999$, third period: $2000-2009$, fourth period: 2010-2014).

Identification of histological subtypes was done according to Rye's classification (Lukes, Craver, Hall, Rappaport, \& Ruben, 1966), REAL/WHO classification (Harris et al., 1999), and WHO 2008 classification (Vardiman et al., 2009). Clinical staging was done according to the Ann Arbor Classification (Carbone, Kaplan, Musshoff, Smithers, \& Tubiana, 1971) and later with its Cotswold's modification (Lister et al., 1989). The prognostic score of the patients was given according to EORTC recommendation in early stage (Tubiana et al., 1989), and International Prognostic Index by Hasenclever and Diehl in advanced stage (Hasenclever \& Diehl, 1998). In advancedstage disease, we considered the prognosis to be standard, when the IPS value was $0-3$, and unfavorable if it was at least 4 . The therapy of the patients occurred due to the current therapeutic protocols (radiotherapy, chemotherapy, or combined radio- and chemotherapy). Primary polychemotherapy was dominantly $\mathrm{CV}(\mathrm{O}) \mathrm{PP}$ (cyclophosphamide, vinblastine (vincristine), procarbazine, prednisone) until 1991, then COPP/ABV (cyclophosphamide, vincristine, procarbazine, prednisone/adriamycin, bleomycin, vinblastine) from 1991, recently ABVD (adriamycin, bleomycin, vinblastine, dacarbazine) from 1999. Salvage protocols 


\section{HOW THE EPIDEMIOLOGY OF HODGKIN LYMPHOMA CHANGED IN DEBRECEN, HUNGARY}

were mainly BEACOPP (bleomycin, etoposide, adriamycin, cyclophosphamide, vincristine, procarbazine, prednisone), DHAP (dexamethasone, cytarabin, cisplatin), and CEP (CCNU, etoposide, chlorambucil, prednisone). The irradiation consisted of extended-field, mantle-field, inverted $\mathrm{Y}$, (sub)total nodal- or involved-field radiotherapy - initially with telecobalt machine, then from 2000 with linear accelerator. Relapsed and refractory disease was treated with high-dose treatment and autologous hematopoietic stem cell transplantation (AHSCT) from the 1990s. Survival data were analyzed using the Kaplan-Meier method by IBM SPSS22 computer software. For the statistical analyses the $\mathrm{chi}^{2}$ test was used. $P<0.05$ was considered significant.

\section{Results}

A total of 715 patients were treated during the investigated period of 34 years. Male to female ratio decreased from 1.29 to 0.97 recently. Mean and median age were decreasing (Table 1).

Age group pattern was unimodal in the first and second periods, with one incidence peak between 20 and 29 years of age. Bimodal age group pattern can be seen in the third and fourth periods with a first incidence peak between 20 and 29 years, and a second incidence peak between 50 and 59 years of age (Figure 1).

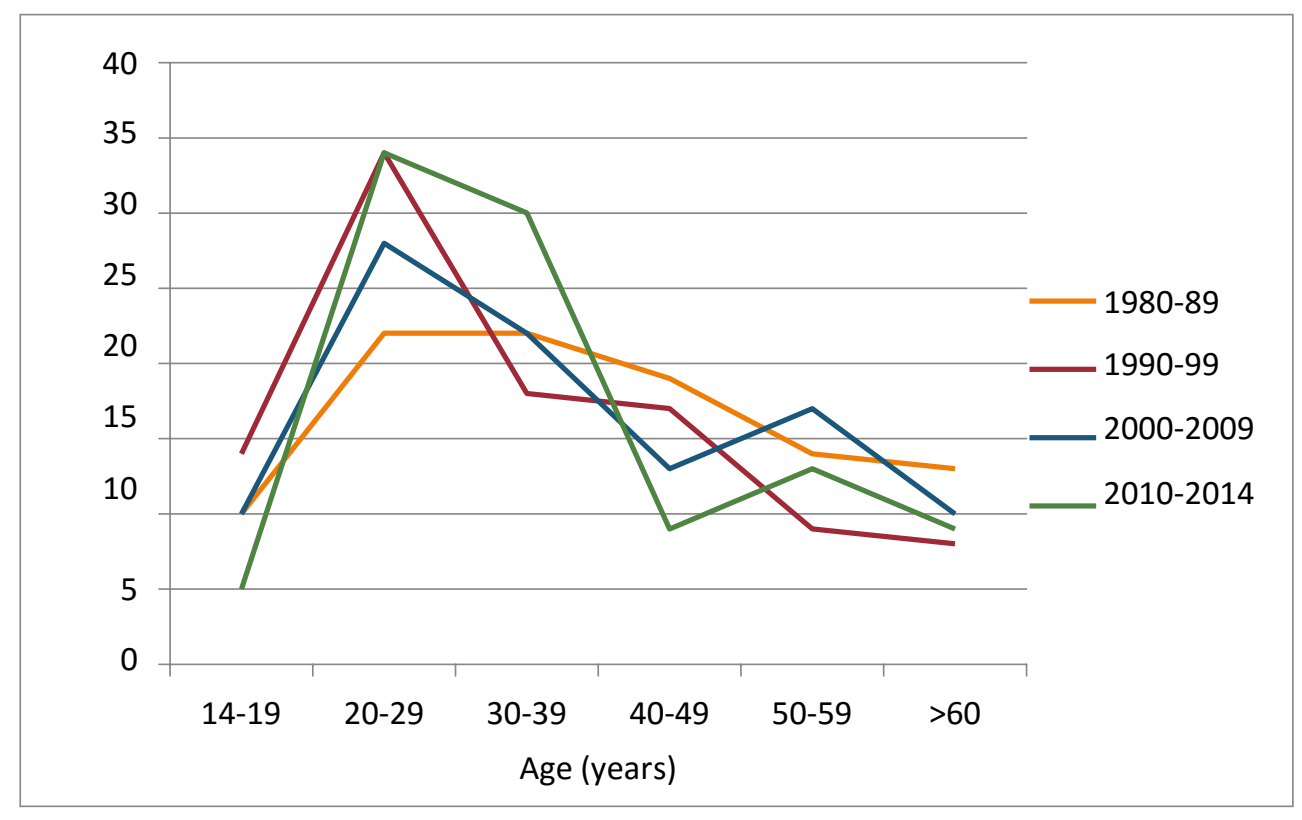

Figure 1.The age group of Hodgkin lymphoma patients during the investigated period 


\section{HOW THE EPIDEMIOLOGY OF HODGKIN LYMPHOMA CHANGED IN DEBRECEN, HUNGARY}

More patients were diagnosed with an early (first-second) stage disease in the third period than in the first and second periods (significantly between the first and third period; $\mathrm{p}<0.001$ ). advanced (third-fourth) stage disease increased again (Figure 2). majority of the patients had B symptoms at the time of the diagnosis regardless of the examined period (Table 1).

In the last five years the ratio of
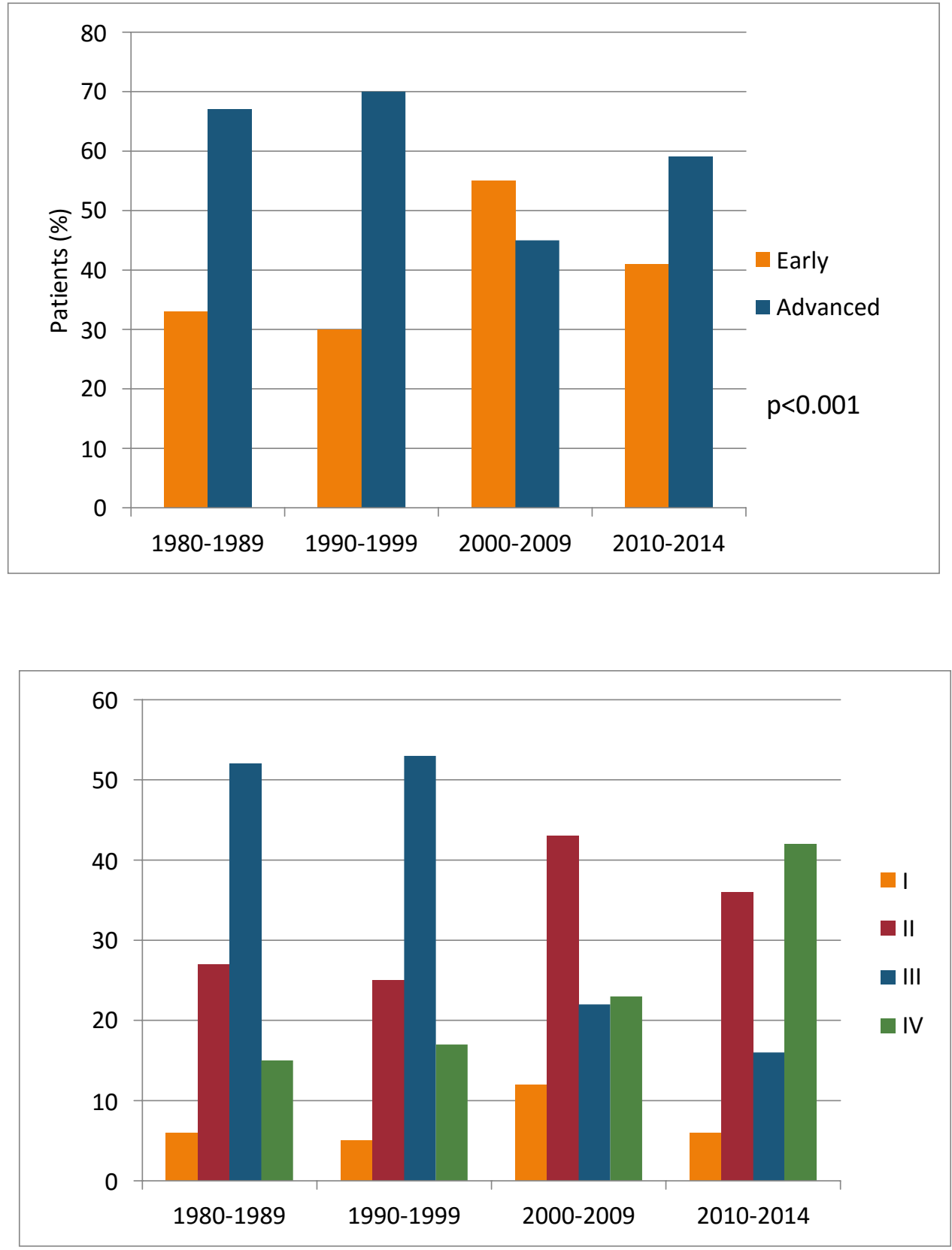

. Figure 2. The distribution of the stages during the investigated periods. 
Medical Research Archives, Volume 4, Issue 6.

HOW THE EPIDEMIOLOGY OF HODGKIN LYMPHOMA

CHANGED IN DEBRECEN, HUNGARY

\begin{tabular}{|c|c|c|c|c|c|c|c|c|}
\hline & $\begin{array}{l}\text { 1980-1989 } \\
\text { Group } 1\end{array}$ & \multicolumn{2}{|c|}{$\begin{array}{c}\text { 1990-1999 } \\
\text { Group } 2\end{array}$} & \multicolumn{2}{|c|}{$\begin{array}{c}2000-2009 \\
\text { Group } 3\end{array}$} & \multicolumn{2}{|c|}{$\begin{array}{c}2010-2014 \\
\text { Group } 4\end{array}$} & \multirow{2}{*}{$\begin{array}{c}\begin{array}{c}\text { Overall } \\
\text { significance } \\
(\text { Gr 1-2-3-4) }\end{array} \\
p\end{array}$} \\
\hline & $\mathbf{N}^{\mathbf{o}}$ & $\mathbf{N}^{\mathbf{o}}$ & $\begin{array}{l}\text { Significance } \\
\text { compared } \\
\text { to Group } 1 \\
(p)\end{array}$ & $\mathbf{N}^{\mathbf{o}}$ & $\begin{array}{c}\text { Significance } \\
\text { compared } \\
\text { to Group } 1 \\
(p)\end{array}$ & $\mathbf{N}^{\mathbf{o}}$ & $\begin{array}{l}\text { Significance } \\
\text { compared } \\
\text { to Group } 1 \\
(p)\end{array}$ & \\
\hline Number of patients & 193 & 199 & - & 236 & - & 87 & - & \\
\hline $\begin{array}{l}\text { Male } \\
\text { Female }\end{array}$ & $\begin{array}{c}109(56.47 \%) \\
84(43.53 \%)\end{array}$ & $\begin{array}{c}110(55.27 \%) \\
89(44.73 \%)\end{array}$ & 0.811 & $\begin{array}{l}120(50.85 \%) \\
116(49.15 \%)\end{array}$ & 0.245 & $\begin{array}{l}43(49.43 \%) \\
44(50.57 \%)\end{array}$ & 0.273 & 0.535 \\
\hline Male/female ratio & 1.29 & 1.23 & - & 1.03 & - & 0.97 & - & \\
\hline Mean age (years) & $39(11-79)$ & $34.5(12-76)$ & - & $38(15-82)$ & - & $\begin{array}{c}36.83 \\
(18-80)\end{array}$ & - & \\
\hline Median age (years) & $37(11-79)$ & $31(12-76)$ & 0.004 & $34(15-82)$ & 0.425 & $33(18-80)$ & 0.302 & 0.028 \\
\hline B symptoms & 96 & 88 & 0.677 & 114 & 0.655 & 48 & 0.544 & 0.774 \\
\hline $\begin{array}{l}\text { Stage } \\
\text { I. } \\
\text { II. } \\
\text { III. } \\
\text { IV. } \\
\text { Data not available }\end{array}$ & $\begin{array}{c}11 \\
51 \\
97 \\
28 \\
6\end{array}$ & $\begin{array}{c}9 \\
45 \\
96 \\
32 \\
17\end{array}$ & 0.854 & $\begin{array}{c}28 \\
100 \\
52 \\
53 \\
3\end{array}$ & $<0.001$ & $\begin{array}{c}5 \\
31 \\
14 \\
37 \\
-\end{array}$ & $<0.001$ & - \\
\hline Early stage disease & 62 & 54 & 0.471 & 128 & $<0.001$ & 36 & 0.186 & $<0.001$ \\
\hline $\begin{array}{l}\text { Advanced stage } \\
\text { disease }\end{array}$ & 125 & 128 & - & 105 & - & 51 & - & - \\
\hline OS (Log-Rank test) & $64.2 \%$ & $84.6 \%$ & $<0.001$ & $87 \%$ & $<0.001$ & $92 \%$ & $<0.001$ & $<0.001$ \\
\hline
\end{tabular}

Table 1. The characteristics of Hodgkin lymphoma patients during the investigated periods. 
The cMC histological subtype was decreasing after continuous increase $(38 \%$, $49 \%, 48 \%$ and $26 \%$ recently; significantly between the first and second/third periods), and cNS subtype was increasing $(21 \%, 28 \%$, $30 \%$, 50\%; significantly in the fourth period) (Figure 3).

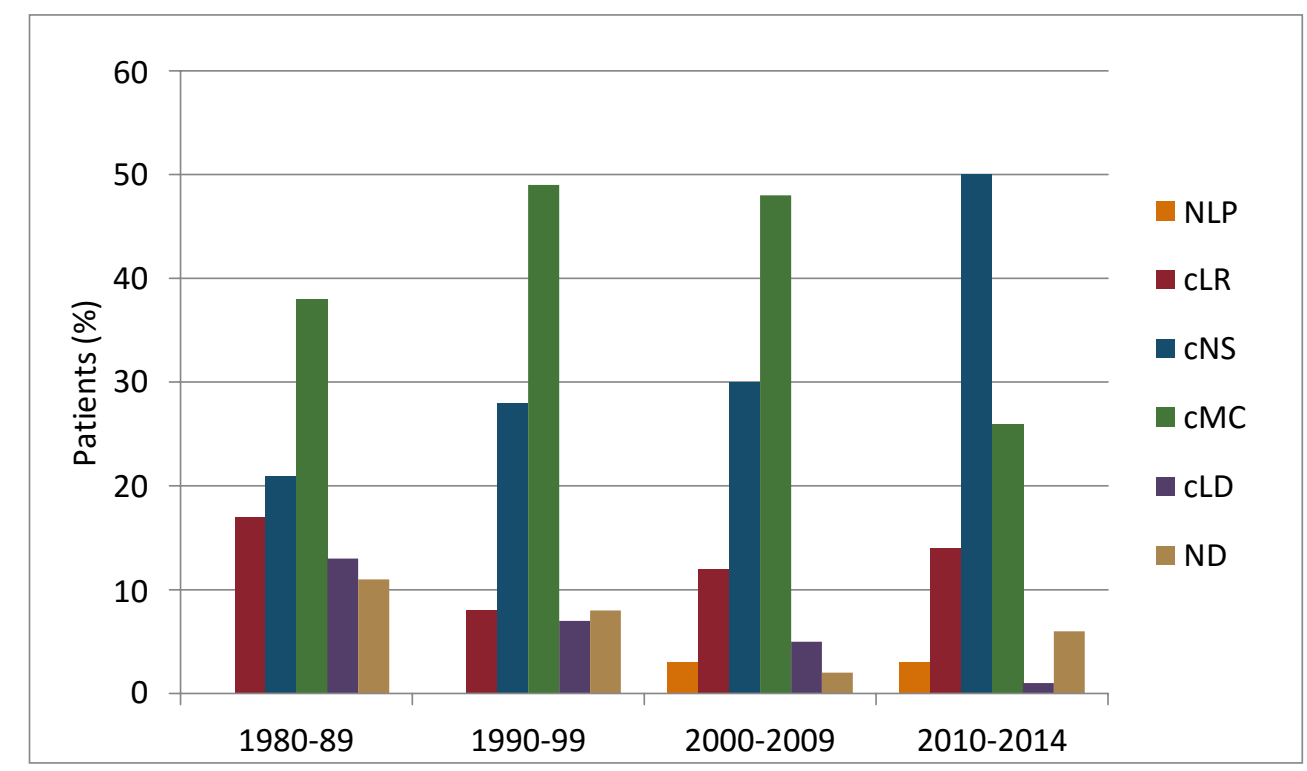

Figure 3. The pattern of the histological subtypes of Hodgkin lymphoma patients during the investigated periods 
The first incidence peak of the age group pattern is the cNS subtype in the third and fourth periods, and the second peak is caused by cMC subtype in the third and cNS in the fourth period (Figure 4).
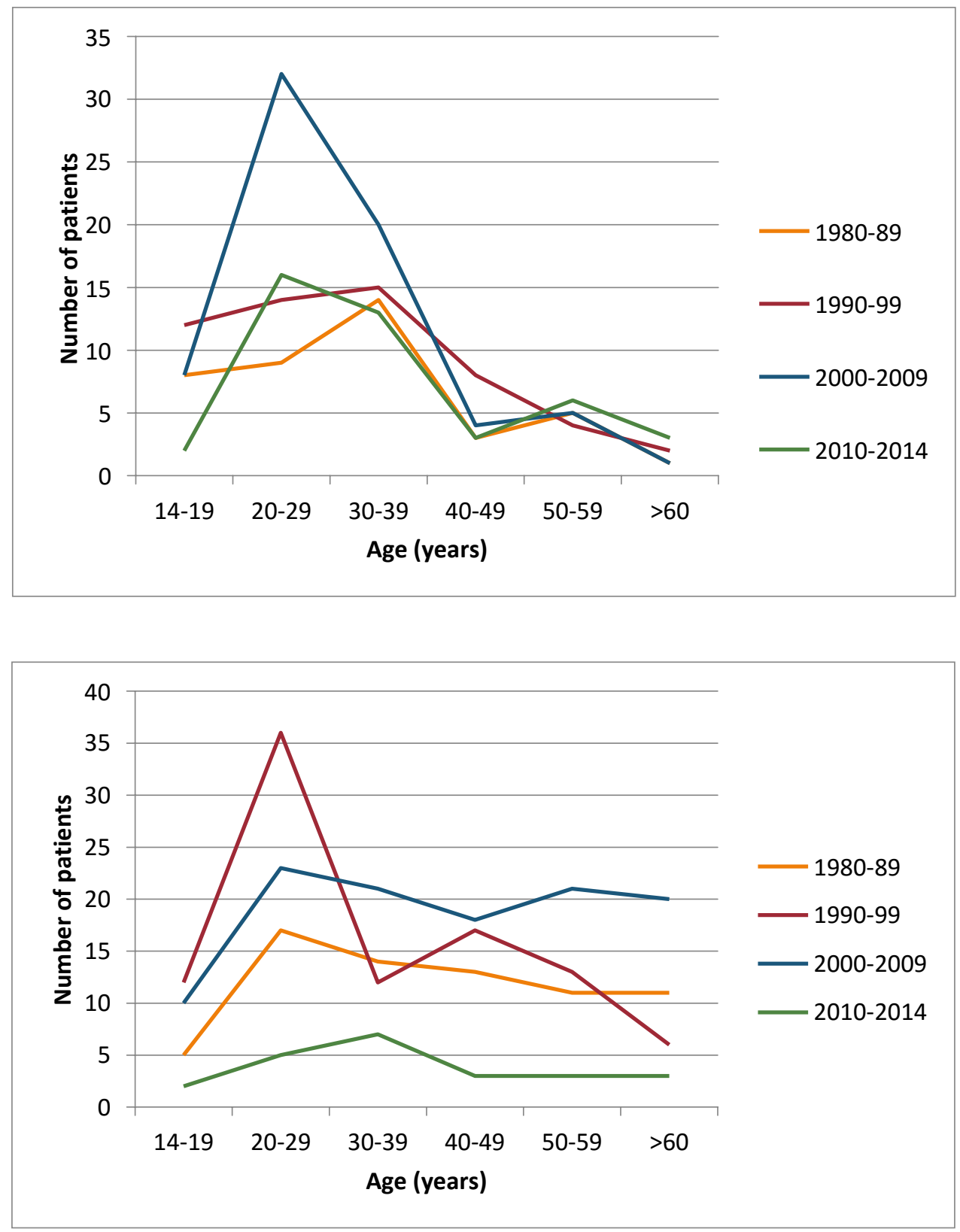

Figure 4. The distribution of classical nodular sclerosis (a) subtype and classical mixed cellularity (b) subtype between age groups during the investigated periods. 


\section{HOW THE EPIDEMIOLOGY OF HODGKIN LYMPHOMA CHANGED IN DEBRECEN, HUNGARY}

Investigating the histological subtypes according to the sexual distribution, the predominance of cMC subtype can be found in the first, second and third periods among males and females. In the fourth period cNS subtype became predominant in both sexes. After a slight increase in the third period, the incidence of cLD histological subtype decreased again in females. The incidence of classical lymphocyte rich (cLR) subtype decreased in the fourth period in both sexes. NLP subtypes were diagnosed in the last two periods with incidence rates of $2.5 \%$ and $3.4 \%$ (Figure 5).
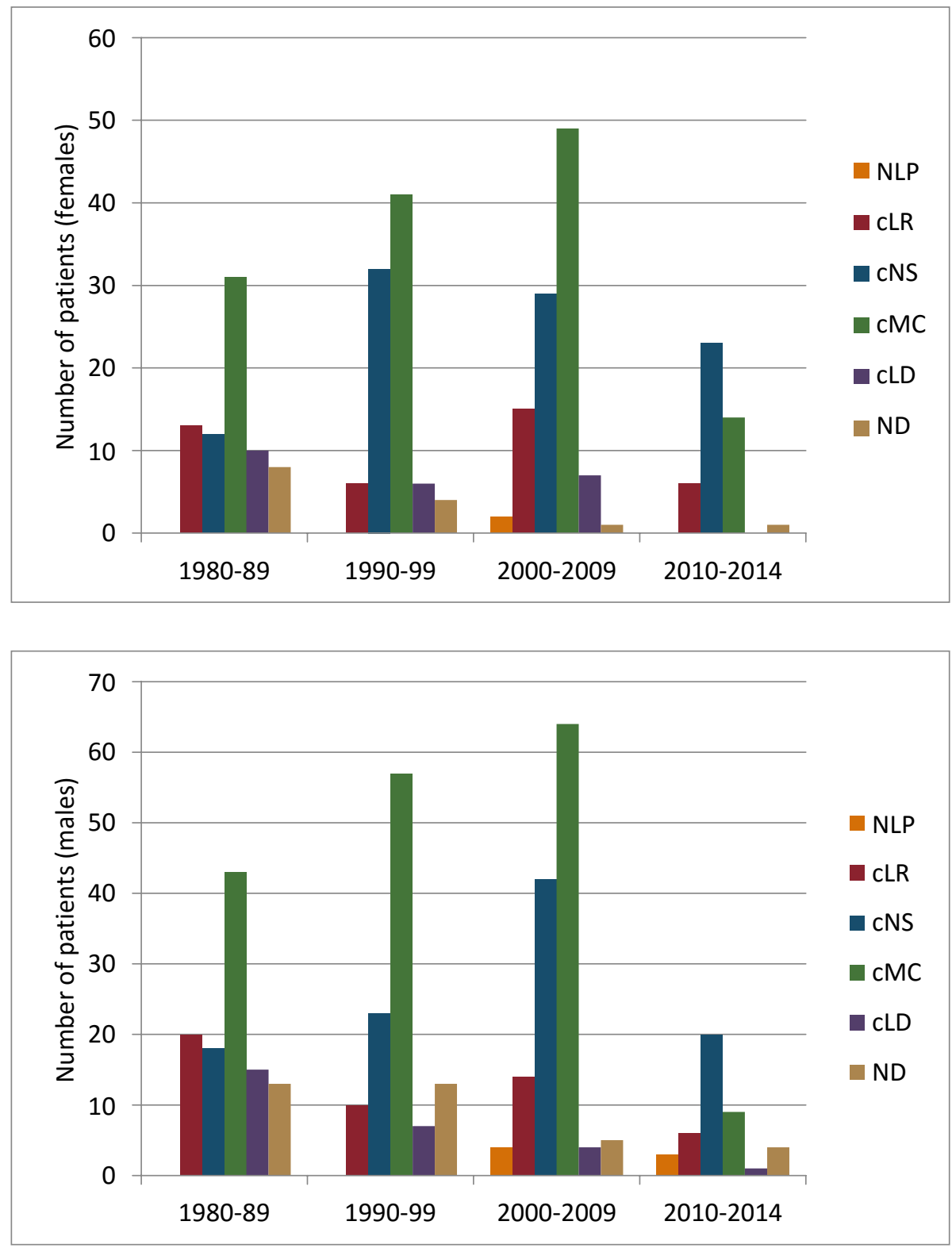

Figure 5. The pattern of the histological subtypes in female (a) and male (b) Hodgkin lymphoma patients during the investigated periods. 


\section{HOW THE EPIDEMIOLOGY OF HODGKIN LYMPHOMA CHANGED IN DEBRECEN, HUNGARY}

Five- and ten-year overall survival (OS) rates significantly increased between the investigated periods. Five-year OS rates were $64.2 \%, 84.6 \%$, $87 \%$ and $92 \%(\mathrm{p}<0.01)$ while ten-year OS rates were $44.4 \%, 76.9 \%$ and $82.3 \%$ (first, second and third periods respectively; $\mathrm{p}<0.01$ ) (Figure 6).

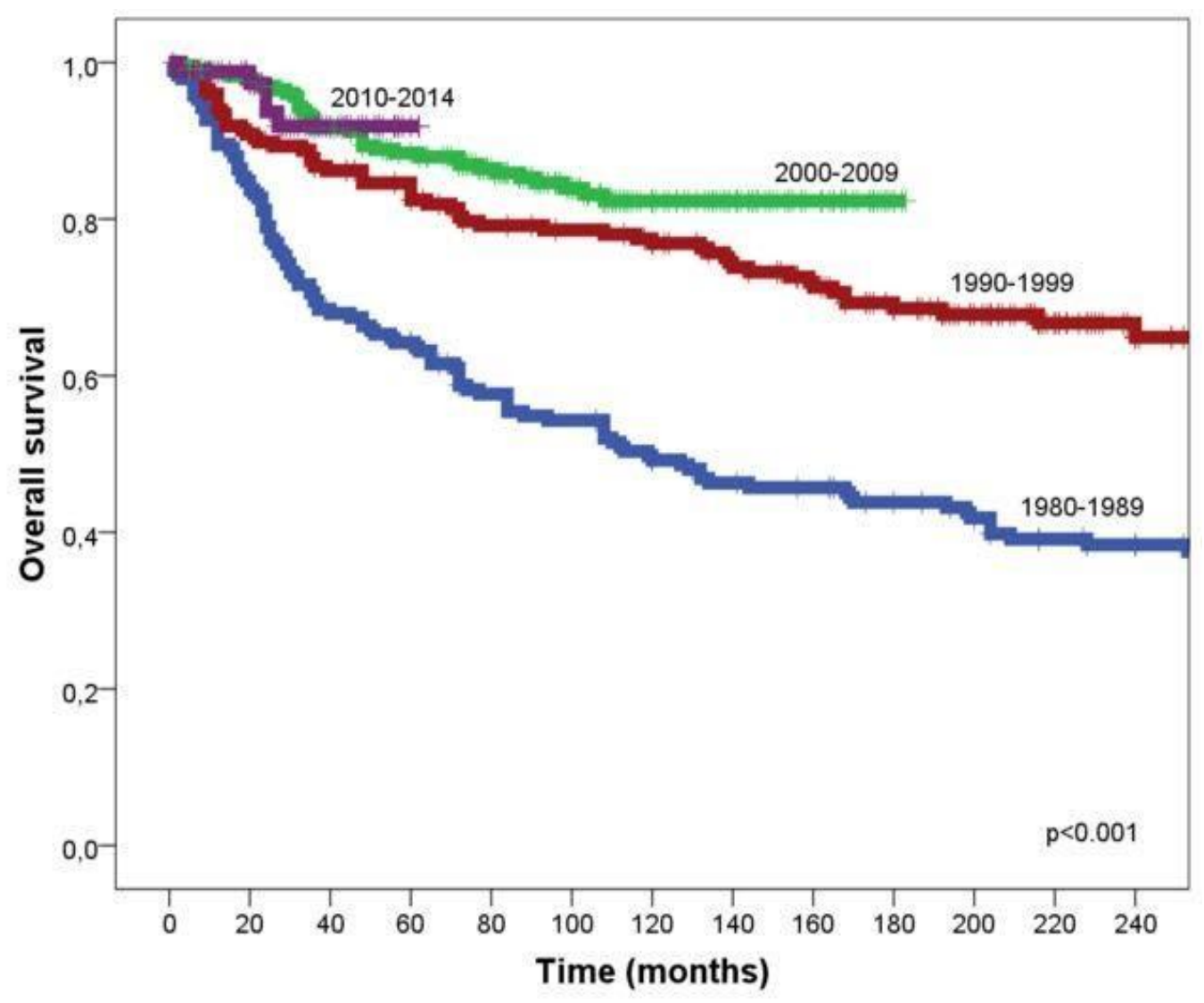

Figure 6.Overall survival of Hodgkin lymphoma patients during the investigated periods.

\section{Discussion}

In the European Union the incidence of HL was 2.6/100 000 among men and 2.1/100 000 among women in 2012. The mortality rate was $0.5 / 100000$ in men and $0.3 / 100000$ in women. In this period incidence was 1.6 (men) and 1.4 (women) in Hungary. In both sexes the incidence was the highest in Croatia and Greece had the highest mortality rates ("European Cancer Observatory International Agency for Research on Cancer," 2016). In the UK about 2000 new
HL cases were diagnosed in 2013. HL is less than $1 \%$ of all new cases in the UK in 2013. Forty-nine percent of HL patients of the UK are diagnosed in people aged 45 and over (2011-2013). Since the late 1970s, HL incidence rates have increased by $7 \%$ in Great Britain, including an increase in females $(15 \%)$ and stable rates in males. Over the last decade, HL incidence rates have increased by a fifth $(20 \%)$ in the UK, with similar increases in females (22\%) and males (18\%) ("Cancer 


\section{HOW THE EPIDEMIOLOGY OF HODGKIN LYMPHOMA CHANGED IN DEBRECEN, HUNGARY}

Research UK," 2016).

In Germany 2200 patients were diagnosed with HL in 2010. The male/female ratio is 1.34. The risk of developing HL at any stage in life is $0.2 \%$ for both men and women. About $10 \%$ of these patients was under 20 years of age at diagnosis. In recent years the incidence rates, and the absolute number of new cases annually, have shown no discernible trends. The mortality rate in Germany in 2010 was just over 300, showing an almost $40 \%$ decrease in the past ten years (Koch Institute \& Centre for Cancer Registry Data, 2014).

In the USA from 2009 to 2013 the incidence of $\mathrm{HL}$ was $2.6 / 100,000$; mortality rate was $0.4 / 100,000$ among men and women per year. In $2013 \mathrm{HL}$ was approximately $0.5 \%$ of all new cancer cases in the USA. Median age was 39 at the time of diagnosis, and unimodal age group pattern was detected (with an incidence peak between 20 and 34 years). The male/female ratio was 1.3 ("LymphomaInfo.net," 2016). Based on the data obtained from the Mediterranean Basin, HL incidence rates are higher in southern Europe, with the exception of Israel and Lebanon. The highest incidence of HL was recorded in Israel $(3.71 / 100$ 000) in 2012, followed by Lebanon (3.67/100 000), Croatia (3.09/100 000), France (2.61/100 000) and Italy $(2.39 / 100000)$. The lowest incidence was measured in Albania (1.1/100 000). Five year survival rates were comparable to those of the United States and other European countries (Salati, Cesaretti, Macchia, Mistiri, \& Federico, 2014).

The incidence of HL in Hungary was 1.6/100 000 in 2012 meaning the country is ranked $36^{\text {th }}$ place in the incidence of the disease among European countries - well below the overall European incidence rate (2.5). Hungarian HL mortality rate was $0.4 / 100000$ in 2012 , ranking the country the $30^{\text {th }}$ in Europe. The European mortality rate was 0.6/100 000 ("European Cancer Observatory International Agency for Research on Cancer," 2016). The authors' single center observations were similar to the previously mentioned data in the means of median age and OS rates. However male to female ratio in the last period was not similar to the male predominance observed in the UK and Germany.

Compared to prior Hungarian nationwide data where an incidence of 1.8/100 000 in HL (between 2000 and 2003) with a 1.27 male to female ratio in a unimodal age group pattern had been identified, the authors' observations strongly differ in the matter of distribution modality (Illés et al., 2004).

In the authors' previous report no significant predominance was found in sexual distribution. This ratio was the result of increasing number of female patients during the third period, which tendency can also be seen in the fourth period. The sexual ratio recently became almost equal. Age at diagnosis shows decreasing tendency, while the predominance of cNS subtype increased.

Similar to the first and second period the majority of the patients were diagnosed in the advanced stage. The decrease of early stage patients and increase in advanced stage disease at diagnosis has significantly $(\mathrm{p}<$ $0.01)$ changed since the third period. The developing diagnostic methods, including the routine use of PET/CT can explain this observation. According to Hutchings et al., in nearly $20 \%$ of the cases PET/CT upstages the disease (Hutchings et al., 2006).

Congruently with the authors' prior observation, the distribution of the histological subtypes is characteristic to the developed countries. In the past five years the predominance of the cNS subtype and significant decrease $(\mathrm{p}<0.01)$ of the cMC subtype were found. Bimodal age group pattern can be observed in the third and fourth periods. The first incidence peak is between 20 and 29 years of age, the second peak is between 50 and 59 years of age. In the investigation's last period both incidence peaks are created by the cNS histological subtype.

According to international data, $80-90 \%$ of HL patients can be cured with modern riskand response adapted treatment regimens. The 10 year OS of HL patients is $75-85 \%$, which are similar to the authors' observations. Five year OS rates significantly $(\mathrm{p}<0.01)$ increased.

In the authors' previous report they established, that the clinical pathological features of HL are changing in Hungary. This 


\section{HOW THE EPIDEMIOLOGY OF HODGKIN LYMPHOMA CHANGED IN DEBRECEN, HUNGARY}

tendency is still present. The epidemiologic pattern, characteristic to the developed countries, was observed at the Department of Hematology, University of Debrecen. High economy status raises patients' socioeconomic status. Diagnostic methods are developing day by day, patients' awareness and educated population can also be a factor in the authors' observations.
The exposition to EBV becomes less common, immunological features are changing, different environmental expositions affect people in rural areas than previously stated. These results and further epidemiological trials from other centers of different geographical locations can help in defining the reasons, proper treatment, and prolonged survival of the disease. 


\section{Medical Research Archives, Volume 4, Issue 6. \\ HOW THE EPIDEMIOLOGY OF HODGKIN LYMPHOMA \\ CHANGED IN DEBRECEN, HUNGARY}

\section{References}

Bonadonna, G., Bonfante, V., Viviani, S., Di Russo, A., Villani, F., \& Valagussa, P. (2004). ABVD plus subtotal nodal versus involvedfield radiotherapy in early-stage Hodgkin's disease: long-term results. Journal of Clinical Oncology: Official Journal of the American Society of Clinical Oncology, 22(14), 2835-41. doi:10.1200/JCO.2004.12.170

Cancer Research UK. (2016). Retrieved from http://www.cancerresearchuk.org/

Carbone, P. P., Kaplan, H. S., Musshoff, K., Smithers, D. W., \& Tubiana, M. (1971). Report of the Committee on Hodgkin's Disease Staging Classification. Cancer Research, 31(11), 1860-1. Retrieved from http://www.ncbi.nlm.nih.gov/pubmed/5121694

Chang, K.-C., Chen, P. C.-H., Jones, D., \& Su, I.-J. (2008). Changing patterns in the frequency of Hodgkin lymphoma subtypes and EpsteinBarr virus association in Taiwan. Cancer Science, 99(2), 345-349. doi:10.1111/j.13497006.2007.00667.x

Engert, A., Diehl, V., Franklin, J., Lohri, A., Dörken, B., Ludwig, W.-D., ... Löffler, M. (2009). Escalated-dose BEACOPP in the treatment of patients with advanced-stage Hodgkin's lymphoma: 10 years of follow-up of the GHSG HD9 study. Journal of Clinical Oncology: Official Journal of the American Society of Clinical Oncology, 27(27), 4548-54. doi:10.1200/JCO.2008.19.8820

European Cancer Observatory - International Agency for Research on Cancer. (2016). Retrieved from http://eco.iarc.fr/

Ferlay, J., Steliarova-Foucher, E., LortetTieulent, J., Rosso, S., Coebergh, J. W. W., Comber, H., ... al., et. (2013). Cancer incidence and mortality patterns in Europe: estimates for 40 countries in 2012. European Journal of Cancer (Oxford, England: 1990), 49(6), 1374-403. doi:10.1016/j.ejca.2012.12.027

Harris, N. L., Jaffe, E. S., Diebold, J., Flandrin, G., Muller-Hermelink, H. K., Vardiman, J.,
... Bloomfield, C. D. (1999). World Health Organization classification of neoplastic diseases of the hematopoietic and lymphoid tissues: report of the Clinical Advisory Committee meeting-Airlie House, Virginia, November 1997. Journal of Clinical Oncology: Official Journal of the American Society of Clinical Oncology, 17(12), 383549. Retrieved from http://www.ncbi.nlm.nih.gov/pubmed/1057785 7

Hasenclever, D., \& Diehl, V. (1998). A prognostic score for advanced Hodgkin's disease.

International Prognostic Factors Project on Advanced Hodgkin's Disease. The New England Journal of Medicine, 339(21), 150614. doi:10.1056/NEJM199811193392104

Hjalgrim, H., Smedby, K. E., Rostgaard, K., Molin, D., Hamilton-Dutoit, S., Chang, E. T., ... Melbye, M. (2007). Infectious mononucleosis, childhood social environment, and risk of Hodgkin lymphoma. Cancer Research, 67(5), 2382-8. doi:10.1158/00085472.CAN-06- 3566

Hutchings, M., Loft, A., Hansen, M., Pedersen, L. M., Berthelsen, A. K., Keiding, S., ... Specht, L. (2006). Position emission tomography with or without computed tomography in the primary staging of Hodgkin's lymphoma. Haematologica, 91(4), 482-9. Retrieved from http://www.ncbi.nlm.nih.gov/pubmed/1658501 5

Illés, Á., Keresztes, K., Miltényi, Z., \& Molnár, Z. (2004). A Hodgkin-kór hazai epidemiológiai és kezelési adatai - A Hodgkin-kór Munkacsoport beszámolója. Hematológia Transzfuziológia, 37(3), 155-165.

Kaye, K. M., Izumi, K. M., \& Kieff, E. (1993). Epstein-Barr virus latent membrane protein 1 is essential for B-lymphocyte growth transformation. Proceedings of the National Academy of Sciences of the United States of America, 90(19), 9150-4. Retrieved from http://www.ncbi.nlm.nih.gov/pubmed/8415670 


\section{HOW THE EPIDEMIOLOGY OF HODGKIN LYMPHOMA CHANGED IN DEBRECEN, HUNGARY}

Koch Institute, R., \& Centre for Cancer Registry Data, G. (2014). German Centre For Cancer Registry Data. Retrieved July 13, 2016, from

http://www.krebsdaten.de/Krebs/EN/Home/ho mepage_node.html

Landgren, O., \& Caporaso, N. E. (2007). New Aspects in Descriptive, Etiologic, and Molecular Epidemiology of Hodgkin's Lymphoma. Hematology/Oncology Clinics of North America, 21(5), 825-840.

doi:10.1016/j.hoc.2007.07.001

Lister, T. A., Crowther, D., Sutcliffe, S. B., Glatstein, E., Canellos, G. P., Young, R. C., ... Tubiana, M. (1989). Report of a committee convened to discuss the evaluation and staging of patients with Hodgkin's disease: Cotswolds meeting. Journal of Clinical Oncology :

Official Journal of the American Society of Clinical Oncology, 7(11), 1630-

6. Retrieved from

http://www.ncbi.nlm.nih.gov/pubmed/2809679

Lukes, R. J., Craver, L. F., Hall, T. C., Rappaport, H., \& Ruben, P. (1966). Report of the Nomenclature Committee. Cancer Research, 26(6 Part 1), 1311-1311.

LymphomaInfo.net. (2016). Retrieved from www.lymphomainfo.net

Miltényi, Z. (2011). Changing Patterns in the Clinical Pathological Features of Hodgkin Lymphoma: A Report from Debrecen, Hungary Z ofia Miltényi, Z ofia Simon, Edit Páyer, Lászí o Vá oczy, Lajos Gergely Adám ona, an Arpád Illés. International Scholarly Research Network ISRN Hematology, 7. doi:10.5402/2011/810708
Salati, M., Cesaretti, M., Macchia, M., Mistiri, M. El, \& Federico, M. (2014).

Epidemiological Overview of Hodgkin Lymphoma across the Mediterranean Basin. Mediterranean Journal of Hematology and Infectious Diseases, 6(1), e2014048. doi:10.4084/MJHID.2014.048

Swerdlow, S. H., Campo, E., Pileri, S. A., Harris, N. L., Stein, H., Siebert, R., ... Jaffe, E. S. (2016). The 2016 revision of the World Health Organization classification of lymphoid neoplasms. Blood, 127(20), 2375-90. doi:10.1182/blood-2016-01-643569

Tubiana, M., Henry-Amar, M., Carde, P., Burgers, J. M., Hayat, M., Van der Schueren, E., ... Thomas, J. (1989). Toward comprehensive management tailored to prognostic factors of patients with clinical stages I and II in Hodgkin's disease. The EORTC Lymphoma Group controlled clinical trials: 1964-1987. Blood, 73(1), 47-56.

Retrieved from

http://www.ncbi.nlm.nih.gov/pubmed/2462943

Vardiman, J. W., Thiele, J., Arber, D. A., Brunning, R. D., Borowitz, M. J., Porwit, A., ... Bloomfield, C. D. (2009). The 2008 revision of the World Health Organization (WHO) classification of myeloid neoplasms and acute leukemia: rationale and important changes. Blood, 114(5), 937-51. doi:10.1182/blood2009-03-209262

Weiss, L. M., Movahed, L. A., Warnke, R. A., \& Sklar, J. (2010). Detection of Epstein-Barr Viral Genomes in Reed-Sternberg Cells of Hodgkin's Disease. http://dx.doi.org/10.1056/NEJM198902233200 806. 